\title{
春髄脊髄動静脈奇形の診断と治療
}

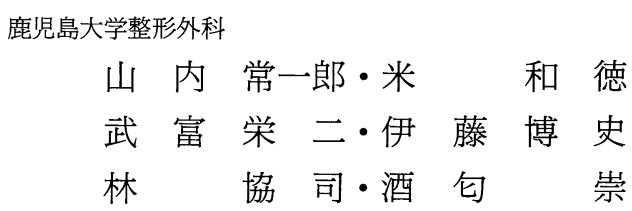

\section{Diagnosis and Treatment of Spinal Arteriovenous Malformations}

\author{
by
}

Joichiro Yamauchi, Kazunori Yone, Eiji Taketomi, Hiroshi Ito, Kyouji Hayashi and Takashi Sakou

Department of Orthopaedic Surgery Faculty of Medicine, Kagoshima University Kagoshima Japan

\begin{abstract}
We report four cases of spinal arteriovenous malformations. While MRI was useful for making an early diagnosis, selective angiography was necessary for the final diagnosis. Embolization was performed in 2 cases, feeder ligation in one case, and another case underwent extraction. Excellent results were achieved in all cases.
\end{abstract}

Key words：MRI (核磁気共鳴映像), Angiography (血管造影), Embolization (塞栓術), Myelography (脊髄造影), AVM (動静脈奇形)

はじめに

脊髄動静脈奇形（以下 AVM）は比較的まれな疾患 であるが，診断と治療に難渋することも少なくない. 今回我々は脊髄動静脈奇形の 4 例を経験したので若干 の考察を加えて報告する。

\section{対 象}

対象は, 全例男性で年齢は $21 \sim 69$ 歳（平均 46 歳） であった。罹病期間は 2 力月〜 1 年 3 力月（平均 8 力 月）であった. AVM の存在高位は頝椎 1 例, 胸椎 2 例, 胸腰椎 1 例で, extra dural type 1 例, dural type 3 例であった. 治療方法は, 頝部脊柱管拡大術 + 摘出術 1 例, 胸椎椎弓切除術 + 凝固 1 例, 遮断術, 塞 栓術 2 例であった。
症

例

症例 1,61 歳の男性である. 平成 4 年 12 月より両 下肢の筋力低下と間欠性跛行および両下肢のしびれが 出現する. 平成 5 年 7 月に腰部脊柱管狭窄症の診断に て腰椎椎弓切除と後側方固定術を施行し症状は軽減す る.同年 10 月に急激に両下肢のしびれと膀胱直腸障 害が出現し, 症状は寛解と増悪を繰り返し, 徐々に悪 化していった。平成 6 年 1 月に AVM の疑いにて再 入院する。同年 2 月に塞栓術を施行するも血流の再開 を来したため椎弓切除を行い直視下に凝固遮断術を施 行し，症状は軽快した。

MRI では T 1 及びT 2 強調像にて T 6 T 12 高位 の脊髄背側に硬膜の不整を認めた。

春髄造影では硬膜管上に蛇行した血管陰影を認める。 血管造影では T 7 高位より feeding で下行性に T 12 高位付近に nidus を認める蛇行した血管造影があり, 


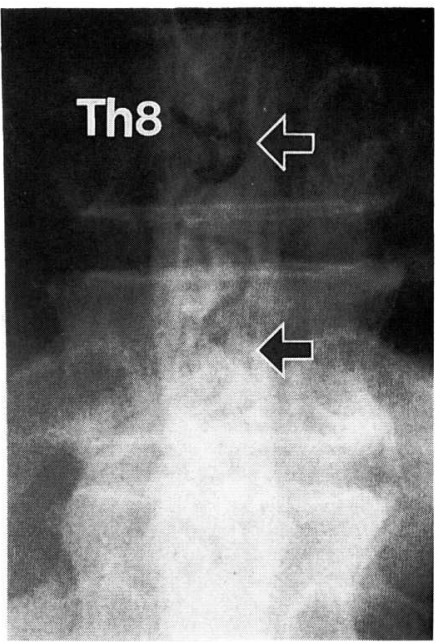

A

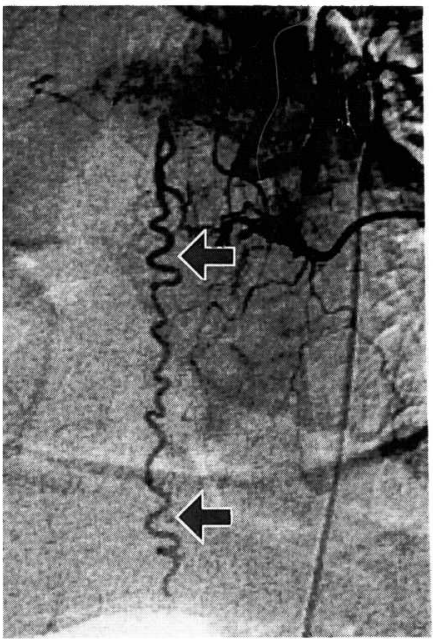

B

図 1 症例 1 脊髄造影と血管造影

$A$ : 春髄造影

B：血管造影

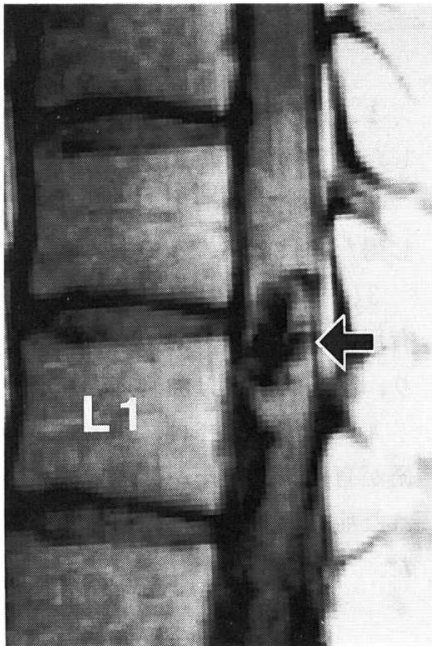

A

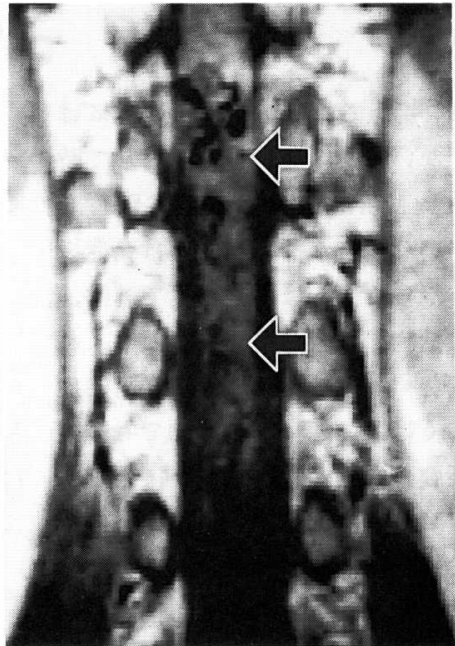

B

図 2 症例 2 MRI

$\mathrm{A}: \mathrm{T} 1$ 強調矢状断面像

B ：T 1 強調冠状断面像

T 10〜 T 12 高位で血管の著明な拡張陰影を認めた (図 1 ).

症例 2,32 歳の男性である. 平成 3 年 3 月より左 层部から大腿後面の激痛と膀胱直障害が出現する。近 医を受診し，保存的治療を受けるも症状の改善が得ら れないため，同年 4 月に当科入院となる．MRI にて AVM と診断し塞栓術を施行し, 症状の改善が得られ
た. MRI では矢状面, 冠状面で T11，12 高位の硬膜 上に蛇行した血管像を認めた（図 2 ).

脊髄造影では T11，12 高位に硬膜管上に蛇行した 血管陰影を認めた。血管造影では T10 高位より feeding で下行性にL 1 高位付近に nidus を認める蛇 行した血管陰影を認めた（図 3 )。 


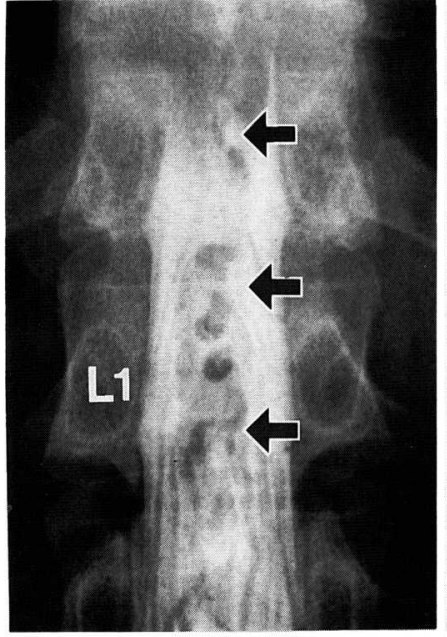

A

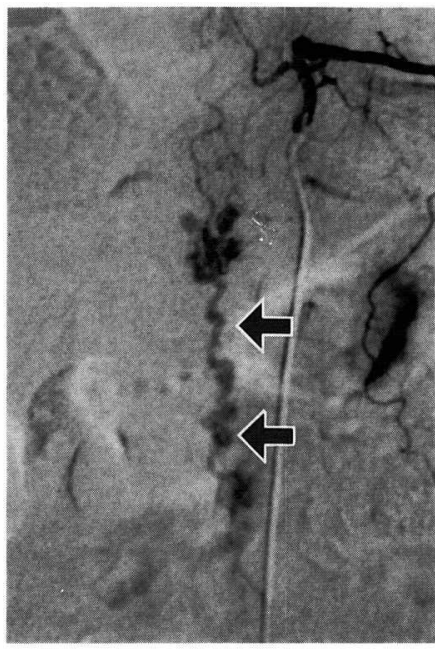

B

図 3 症例 2 沗髄造影と血管造影

$\mathrm{A}$ : 脊髄造影

B：血管造影

考

察

AVM は比較的まれな疾患であるが, その診断には 難渋することも少なくない. 臨床症状の特徵として時 間的な寛解, 増悪があり Merland らは間歇性跛行を 認めることを強調している，また括約筋障害は発症後 まもなく出現することが多く, しばしば重篤で運動, 知覚障害が軽い時期に括約筋障害が目立つこともまれ でないと述べている122). しかし，必ずしも定型的症 状が出現することは多くはない. 今回の症例でも頝椎 部の症例では術前, 硬膜外血腫と診断したが, 術中所 見と病理所見にて AVM の診断が得られた。胸椎部 の症例にても L 5 の神経症状, 間歇性跛行など認め, 初期には腰部脊柱管狭窄症と誤って診断した. 診断に はMRIが有用であったが, MRIのみにては, 診断が 困難なことも少なくなく, 確定診断には血管造影が必 要であった ${ }^{3)}$.

治療は髄内に病変が及ぶものは全摘が困難であり, 塞栓術が有用であった。しかし Dural typeの中でも 塞栓術にて血流の再開を認められる症例もあり，この ような例では直視下の凝固遮断術が有効であった。
結語

1. 比較的まれな脊髄脊髄動静脈奇形の 4 例を経験 したので報告した。

2. 診断に難渋することも少なくなく初期より診断 し得たのは 1 例のみであった。

3.スクリーニング検査としては，MRI が比較的 有用であったが，MRIのみでは診断が困難な例もあ り，確定診断には血管造影が必要であった。

4.治療としては, dural typeに対しては, 塞栓 術が有効であったが，塞栓術にて血流の再開が認めら れた症例に対しては，直視下に凝固，遮断術が行われ た。

\section{参 考 文 献}

1) Aminoff MJ, Jogue $V$ : Clinical features of spinal vascular malformations. Brain $97: 197-210,1974$.

2）伊藤秀文，日下博文，今井輝国：春䯣血管奇形の症候学. 春椎脊髄 2 . 483-491, 1989.

3）町田 徹, 山川健太: 脊髄脊髄動静脈奇形の画像診断. 脊椎脊髄 2 . 493-499, 1989. 